\title{
What Factors Impact Financial Behavior Other than Financial Literacy?
}

By

Chad Jones, University of South Florida

I n Huston's (2010) framework, which is widely accepted within the research on financial literacy since 2010, reveals that while financial literacy is certainly part of the story influencing financial behavior, it is not the whole story. We see that Huston includes "other factors" as informing financial behavior as well. Additionally, there's conflicting evidence within the literature reviewed that calls into question financial literacy as the strongest predictor of financial behavior. Given that pursuing an exhaustive list of "other
Financial literacy has a well-researched correlation with financial behavior. However, not only is financial literacy not a lone actor, it may be less significant than many others in impacting financial behavior. outside of financial literacy that have an evident correlation to financial behavior according to their perception based on client interactions. Having this short list of factors from experts could lead to follow-on research determining the strength of correlation among the identified factors, to include financial literacy. If future research were to identify a factor(s) that had a stronger correlation to financial behavior than financial literacy, it may impact the current push for policy to embolden financial education efforts to improve financial literacy factors" might prove indeterminable, financial advisors will be surveyed as a proxy for financial behavior subject matter experts to identify some of the more commonly accepted factors alone as a means to improve financial behavior. Additionally, we may be able to remove the stigma that low financial literacy equates to an inability to win with personal finances.

Keywords: Financial literacy, financial behavior, financial planners, self-efficacy, self-control 
The context of this Research Question Review is to shed light on whether financial literacy is as impactful as the current research seems to suggest over other factors or influences. The existing research also includes several studies that do not seem to agree regarding the strength of correlation when it comes to financial literacy. While most are not academics, nor aware of the existing literature on the subject, most practitioners, it is hypothesized, would mention several other antecedents as having just as much impact if not more so than financial literacy. Additionally, it's hypothesized that some experts would see a negative correlation between financial literacy and financial management behavior. If these supposed opinions are shown to be generalizable across the industry of advisors and planners, it would have a major impact for managers in determining ideal clients (potentially through the use of a questionnaire) and how to best leverage technology, specifically video platforms, to encourage and or shape the identified antecedents to behavior. Some factors identified may be changeable (e.g. self-efficacy and self-control) while other factors identified may not (e.g. personality, romantic partner, and past experiences). Identifying which factors are impactful and malleable could help increase an advisor's assets under management, strengthen the client-relationship and attract prospective clients by being able to apply treatment(s) to positively modify outcomes in client behavior.

\section{Literature Summary}

The purpose of the following tables serves to reflect an impotence of research due to the increasing complexity of understanding financial literacy as a means to understand financial behavior, and, ultimately, well-being. What is 'useful' and what is 'truth' have seemingly diverged. Grandon Gill (2011) stated that when this happens, "we are motivated to validate truths that are widely accepted" and are therefore "seduced by our research." This review proposes that what is useful is identifying and understanding other factors that impact financial behavior as the experts see it. Using the image of an elephant and its rider as

\section{Protocol}

The primary research tool to explore the literature was the ABI/Global Database via the Library Services link on MyUSF portal. After conducting a pilot study of 11 interviews (April 6-15, 2020), each interview was coded to reveal constructs that would inform keyword searches. Each search was conducted as an "Advanced Search" with the parameters Full Text and Peer Reviewed selected. Ultimately, 35 articles were downloaded and captured in EndNote, while 32 are cited. During the search, a meta-analysis paper (Fernandes, Lynch, \& Netemeyer, 2014) was found, lending significantly to the literature used beyond text string searches.

analogy, financial literacy appears to be the rider, a rational actor assumed by most to be what steers and determines the elephant's path. The elephant, however, may be, according to the author of the analogy, the emotional drive or state that impacts the human mind, taking the rider along a path the animal is ultimately controlling (Haidt 2006). The order, therefore, of the tables is to familiarize the reader with the existing research on literacy, what the research tells us about other factors, and the impact of experts on behavior.

Table 1 defines the base constructs of financial literacy and financial behavior. Interestingly, after 50 years of research there is still no widely accepted operational definition of financial literacy. Huston stated in 2010 which included 72 studies on financial literacy that "although several financial literacy definitions have been proposed, there is no universally accepted meaning". Additionally, according to Huston, "there currently are no standardized instruments to measure financial literacy" (2010).

Table 2 is meant to reflect the almost dichotomous nature of the existing research on financial literacy. While there is a very healthy amount of research that declares financial literacy as a positively correlated factor of financial behavior, the meta-analy-

Table 1: Defining the Base Constructs

\section{Finding}

Financial literacy is the ability to understand and apply personal finance information.

Financial behavior refers to money management behavior regarding saving and investing, credit, cash and insurance.

\section{SourceReferences}

(J. E. P. C. Grable, Joo, \& Park, 2015); (Bapat, 2019); (Huston, 2010); (Shih \& Ke, 2014); (Stolper \& Walter, 2017); (Sundarasen, Rahman, Othman, \& Danaraj, 2016)

(Bapat, 2019); (Dew \& Xiao, 2011) 
Table 2: Financial Literacy as an Antecedent to Financial Behavior

Central Theme

Financial knowledge has strong positive correlation with financial literacy. Financial literacy has a strong correlation with financial behavior.

Financial literacy's correlation to financial behavior is weak at best

There is conflicting evidence of Financial Literacy's impact on Financial Behavior

sis found and cited within, reveals a level of impact that seems to belie the effectiveness of policy changes and championed educational programs meant to improve financial behavior.

Table 3 offers research that has revealed antecedents of financial behavior outside of financial literacy. That is not to suggest that all or any of the factors are mutually exclusive from each other, but, rather, that the 'other factors' conceded in Figure 1 have, potentially, a small group of players that seem to emerge as common antecedents. The studies cited in this table, however, all have a targeted sample frame that do not include industry experts regarding financial management. That is to say, the experts are not being interviewed or surveyed regarding the factors that impact financial behavior.

Table 4 reflects the relationship between experts such as financial planners and their clients. The research clearly demonstrates the effectiveness of professional advisory in matters of personal finance. Behavior in these scenarios are positively affected and are shown to be more consistent. Therefore, financial planners are an excellent proxy for financial behavior expertise to contrast the expertise of academia, if indeed the assumption of falling in love with the existing literature on the impact of financial literacy is valid.

Table 5 shows the existing scales and questionnaires within the current literature intended to identify and even predict financial behaviors. The Klontz study is the only paper found that included financial planners, though not exclusively, within the sample of respondents. The scales found for self-efficacy, self-control, attitude and financial literacy will be used to identify and modify items for a data gathering survey.

\section{Conceptual Model}

From Huston's Framework in 2010, the review of the literature since coupled with a pilot study of inter-
Sources

(Huston, 2010); (Tang \& Peter, 2015);

(J. E. P. C. Grable et al., 2015)
(Frijns, Gilbert, \& Tourani-Rad, 2014);

(Fernandes, Lynch, \& Netemeyer,

2014)

\begin{tabular}{|l} 
(Frijns, Gilbert, \& Tourani-Rad, \\
$2014) ;$ \\
(Fernandes, Lynch, \& Netemeyer, \\
$2014)$
\end{tabular}

viewed advisors, seems to point to an imbalance of antecedents and their depth of respective research, especially from the practitioner's perspective. In Figure 1, the graphic on the left is pulled directly from Huston's paper on measuring financial literacy (Huston 2011). The graphic on the right titled Practitioner Perception uses scale to represent level of perceived impact by financial literacy as compared to a handful of other labeled factors (admittedly among many more, represented by smaller un-labeled circles) that were consistently revealed during a pilot study of 11 interviews with practitioners.

\section{Discussion}

Summarily, there seems to be two issues at hand: 1) research has fallen in love with financial literacy, paying relatively little attention to potentially more impactful antecedents to financial behavior and 2) research has largely ignored the practitioner (namely advisors and planners) in their sample frames.

Financial literacy has become a highly researched and debated issue over the last 50 years. In that time, there has been no consensus on an operational definition nor an agreed upon metric for financial literacy. However, financial literacy is commonly the scapegoat of academics and policymakers, alike, for explaining the deficit in financial behavior among US households. We also find in the literature support for other antecedents for financial behavior (see Table 3). This research is not nearly as extensive as the literature regarding financial literacy, but the groundwork is being laid for understanding financial behavior and its many influences in a broader context than formal education.

With the multitude of studies surrounding financial literacy, it was not surprising to find a meta-analysis conducted in 2014 studying the effect size of over 201 papers. The meta-analysis itself has been cited over one thousand times according to Google 
Table 3: Other Factors as Antecedents to Financial Behavior other than Financial Literacy

\section{Construct}

Self-Efficacy: a personal judgment of how well one can execute courses of action required to deal with prospective situations (Bandura et al. 1999).

\section{Source}

(Lim, Heckman, Montalto, - Self-efficacy moderates help-seeking behav\& Letkiewicz, 2014)

(Asebedo \& Seay, 2018)

- Financial Self-Efficacy is important to saving behavior in the years preceding retirement when income peaks and competing demands on that income (save vs. spend) intensify.

(Letkiewicz, Robinson, \& - A society high in self-efficacy may make Domian, 2016)

(Asaad, 2015) greater use of financial planners

- Confidence is a necessary component to transferring literacy to practice. However, unchecked confidence can have detrimental financial impact.

Self-Control: the ability to control oneself, in particular one's emotions and desires or the expression of them in one's behavior, especially in difficult situations.

\begin{tabular}{l} 
\\
\hline $\begin{array}{l}\text { Attitude: refers to } \\
\text { feelings, beliefs and } \\
\text { behavior predispositions } \\
\text { directed towards people, } \\
\text { groups, ideas or objects. } \\
\text { It influences the behav- } \\
\text { ior of the individuals. }\end{array}$ \\
\hline $\begin{array}{l}\text { Romantic Partner/Fam- } \\
\text { ily: spouse, significant } \\
\text { other, adult family mem- } \\
\text { bers. }\end{array}$ \\
$\begin{array}{l}\text { Past Experience: } \\
\text { past events, knowledge, } \\
\text { and feelings that make } \\
\text { up someone's life or } \\
\text { character. }\end{array}$ \\
\hline
\end{tabular}

(Fisher, 1930)

(Strömbäck, Lind, Skagerlund, Västfjäll, \& Tinghög, 2017)

(Shefrin \& Thaler, 1988)

(Strömbäck et al., 2017)

(Curran, Parrott, Sun Young, Serido, \& Shim, 2018)

(Jorgensen, Rappleyea, Schweichler, Fang, \& Moran, 2017); (Gudmunson \& Danes, 2011)

- Self-control is necessary because immediate consumption is always an attractive alternative to retirement savings.

- Effort of attention is the essential phenomenon of will.

- People with good self-control are more likely to save money from every pay-check, have better general financial behavior, feel less anxious about financial matters, and feel more secure in their current and future financial situation.

- Respondents who were more optimistic demonstrated better financial behavior, were less anxious about financial matters, and were more confident about their financial situation.

(Frijns et al., 2014)

Scholar. The meta-analysis determined that "interventions to improve financial literacy accounts for less than $0.1 \%$ of the variance in downstream financial behaviors studied (Fernandes et al., 2014).” This was a surprising statistic to read given the volume of research dedicated to dissecting financial literacy and how the results may be used to bolster behavior through intervention. Millions, if not billions, have

been spent and lobbied for to create programs across the US to improve financial education at many different levels from junior high school through programs offered at work for adults. The meta-analysis is telling us that, so far, these programs have been largely ineffective in shaping better financial behaviors. 
Table 4: Impact of Financial Planners on Financial Behavior

Central Theme Finding

Sources

Financial planners add Having a professional financial planner can gen"gamma" due to expertise and creativity in developing an income plan.

erate more income from given assets due to expertise. "Gamma," is designed to measure the additional expected retirement income achieved by an individual investor making intelligent financial-planning decisions.

Financial planners positively effect financial behavior

The study's major finding is that working with an advisor is related to several important financial planning activities, including goal setting, calculation of retirement needs, retirement account diversification, use of supplemental retirement accounts, accumulation of emergency funds, positive behavioral responses to the recent economic crisis, and retirement confidence.

Financial planners provide consistency of behavior

Financial planners impact behavior in all dimensions (saving, investing, cash, credit, insurance)
We find that interventions to improve financial literacy explain only $0.1 \%$ of the variance in financial behaviors studied.

Comprehensive wealth management is preferred over simple investment portfolio management. Personal finance practices and considerations are key to consumers.
(Blanchett \& Kaplan, 2013)

(Marsden, Zick, \& Mayer, 2011)

(Fernandes, Lynch, \& Netemeyer, 2014)

(Warschauer \& Sciglimpaglia, 2012); (J. E. Grable \& Chatterjee, 2014)

Table 5: Scales and Questionnaires

\section{Finding}

Financial planners involved in the development process of survey items

Tool predictive of participants' actual levels of savings and consumer debt

Multifaceted measure of Brief Money Management Scale money management to better understand the antecedents and consequences of different financial decisions

Existing scale for Self-efficacy

Existing scale for Self-control

Existing scale for Attitude

\begin{tabular}{|l} 
\\
\hline Existing scale for Financial \\
Literacy
\end{tabular}

Fina (Google Scholar) (Google Scholar) (Google Scholar) (Google Scholar)
Instrument

Klontz Money Script Inventory (questionnaire)
Sources

(B. Klontz, Britt, Mentzer, \& Klontz, 2011); (B. T. Klontz \& Britt, 2012)

(Dew \& Xiao, 2011)

Management Behavior

(Ksendzova, Donnelly, \& Howell, 2017)

Cronbach's Alpha: 0.91; Cited 257

Cronbach's Alpha: 0.89; Cited 5318

Cronbach's Alpha: 0.839; Cited 132

Cronbach's Alpha: 0.85; Cited 153
(Knoll \& Houts, 2012)

(Kurbanoglu, Akkoyunlu \& Umay, 2006)

(Tangney, Baumeister \& Boone, 2004)

(Edison \& Geissler, 2003) 
Relations among Financial Literacy, Knowledge, Education, Behavior and Well-Being



(Huston, 2010)

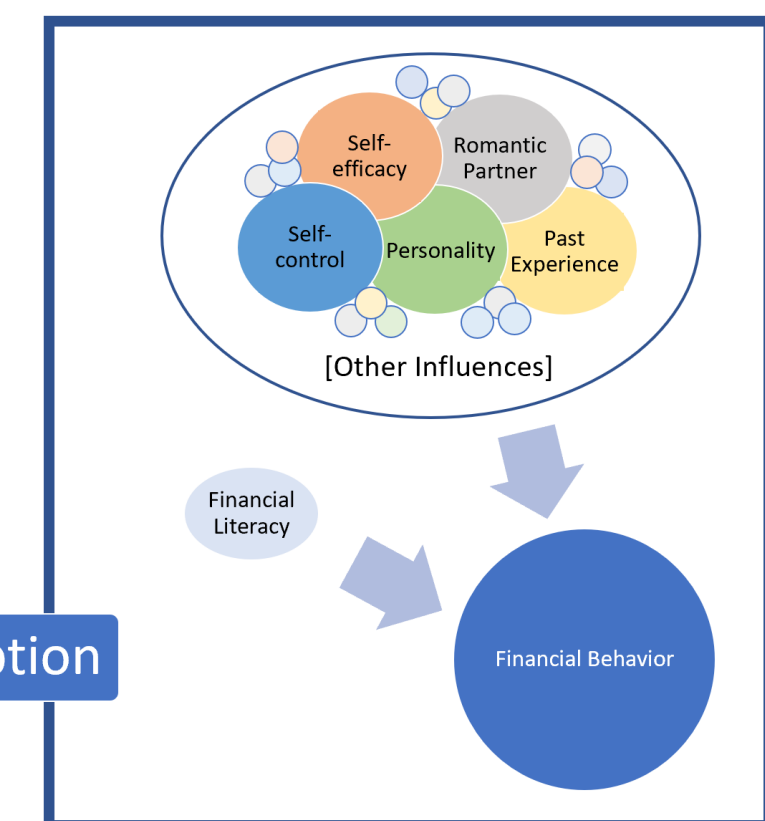

\section{Figure 1: Academic vs. Practioner Perspectives on Financial Behavior}

Another surprise was finding very little research where wealth management experts were targeted to expound the literature surrounding financial behavior. In conducting this review, it became evident that the largely missing sample frame of practitioners was potentially detrimental to the direction and depth of research findings. The very experts that coach and solicit financial behavior should be asked to lend their voice in suggesting what the determinants of financial behavior may be, based on their interactions with clients and their families.

When we have the opinion of experts on the matter coupled with the work done by academia, we have a potentially fuller perspective on how to apply treatment to improve the financial behavior of US households.

\section{Conclusions}

The context of this Research Question Review was to identify antecedents outside of financial literacy. Clearly, financial literacy is a correlated antecedent, but 50 years of research has done little to identify the most impactful antecedents and has largely ignored a subset of expertise. Additionally, it's hypothesized by some experts that we may find a negative correlation between financial literacy and financial management behavior. That is to say that some experts in identifying such antecedents as self-efficacy and self-control would potential relate experiences where increased financial literacy may lead to over-confident and impulsive financial behavior. Certainly, the research outlined above gives cause to explore this largely un-tapped field of respondents as a means to fill a gap in the literature and converge what is truth with what is useful.

Key Takeaways:

- Financial Literacy has long been studied as 'the' antecedent when it comes to financial behavior. Interestingly, in those 50 years of research articles, there still does not exist a widely accepted operational definition or metric of the construct.

- Other factors impacting Financial Behavior are varied and numerous, but several have been identified for their impact (controlling for basic demographics).

- A thorough meta-analysis in 2014 revealed a less than $0.1 \%$ effect of intervention of Financial Literacy improvement programs on Financial Behavior.

- Plenty of research supports Financial Planners as able to shape Financial Behavior resulting in more consistent wealth, better portfolio performance and more creative income strategy.

- Very little research has consulted, or used as a sample frame, practitioners (Financial Planners) in determining survey items to create instruments meant to identify and predict financial behavior.

- If practitioners can help identify and predict behavior, we can potentially apply treatment to better modify outcomes.

There may exist a potential new line of research that includes financial experts within the sample frames and tries to identify the strength of different antecedents in their impact upon financial behavior. If 
such research were to reveal antecedents of greater importance, potentially, social and educational programs can be improved to greatly enhance downstream financial behaviors, motivating economic growth and reducing poverty and criminal activity.

\section{References}

Asaad, C. T. (2015). Financial literacy and financial behavior: Assessing knowledge and confidence. Financial Services Review, 24(2), 101-117.

Asebedo, S. D., \& Seay, M. C. (2018). Financial Self-Efficacy and the Saving Behavior of Older Pre-Retirees. Journal of Financial Counseling and Planning, 29(2), 357-368. https://doi. org/10.1891/1052-3073.29.2.357

Bandura, A., Freeman, W., \& Lightsey, R. (1999). Self-efficacy: The exercise of control. In: Springer.

Bapat, D. (2019). Exploring Antecedents to Financial Management Behavior for Young Adults. Journal of Financial Counseling and Planning, 30(1), 4455. https://doi.org/10.1891/1052-3073.30.1.44

Blanchett, D., \& Kaplan, P. (2013). Alpha, beta, and now... gamma. The Journal of Retirement, 1(2), 29-45. https://doi.org/10.3905/jor.2013.1.2.029

Curran, M. A., Parrott, E., Sun Young, A., Serido, J., \& Shim, S. (2018). Young Adults' Life Outcomes and Well-Being: Perceived Financial Socialization from Parents, the Romantic Partner, and Young Adults' Own Financial Behaviors. Journal of family and economic issues, 39(3), 445-456. https://doi. org/10.1007/s10834-018-9572-9

Dew, J., \& Xiao, J. J. (2011). The financial management behavior scale: Development and validation. Journal of Financial Counseling and Planning, 22(1), 43.

Edison, S. W., \& Geissler, G. L. (2003). Measuring attitudes towards general technology: Antecedents, hypotheses and scale development. Journal of targeting, Measurement and Analysis for Marketing, 12(2), 137-156. https://doi.org/10.1057/palgrave. jt. 5740104

Fernandes, D., Lynch, J. G., \& Netemeyer, R. G. (2014). Financial literacy, financial education, and downstream financial behaviors. Management science, 60(8), 1861-1883. https://doi.org/10.1287/ mnsc.2013.1849

Fisher, I. (1930). Theory of interest: as determined by impatience to spend income and opportunity to invest it: Augustusm Kelly Publishers, Clifton.

Frijns, B., Gilbert, A., \& Tourani-Rad, A. (2014). Learning by doing: the role of financial experience in financial literacy. Journal of Public Policy, 34(1), 123-154. https://doi.org/10.1017/ $\underline{\text { S0143814X13000275 }}$
Grable, J. E., \& Chatterjee, S. (2014). Reducing wealth volatility: The value of financial advice as measured by zeta. Journal of Financial Planning, 27(8), 45-51.

Grable, J. E. P. C., Joo, S.-H. P., \& Park, J. P. (2015). Exploring the Antecedents of Financial Behavior for Asians and Non-Hispanic Whites: The Role of Financial Capability and Locus of Control. Journal of Personal Finance, 14(1), 28-37.

Gudmunson, C. G., \& Danes, S. M. (2011). Family Financial Socialization: Theory and Critical Review. Journal of family and economic issues, 32(4), 644-667. https://doi.org/10.1007/s10834-0119275-y

Huston, S. J. (2010). Measuring Financial Literacy. Journal of Consumer Affairs, 44(2), 296-316. https://doi.org/10.1111/j.1745-6606.2010.01170.x

Jorgensen, B. L., Rappleyea, D. L., Schweichler, J. T., Fang, X., \& Moran, M. E. (2017). The Financial Behavior of Emerging Adults: A Family Financial Socialization Approach. Journal of family and economic issues, 38(1), 57-69. https://doi.org/10.1007/ $\underline{\text { s10834-015-9481-0 }}$

Klontz, B., Britt, S. L., Mentzer, J., \& Klontz, T. (2011). Money beliefs and financial behaviors: Development of the Klontz Money Script Inventory. Journal of Financial Therapy, 2(1), 1. https:// doi.org/10.4148/jft.v2i1.451

Klontz, B. T., \& Britt, S. L. (2012). How clients' money scripts predict their financial behaviors. Journal of Financial Planning, 25(11), 33-43.

Knoll, M. A., \& Houts, C. R. (2012). The financial knowledge scale: An application of item response theory to the assessment of financial literacy. Journal of Consumer Affairs, 46(3), 381-410. https:// doi.org/10.1111/j.1745-6606.2012.01241.x

Ksendzova, M., Donnelly, G. E., \& Howell, R. T. (2017). A brief money management scale and its associations with personality, financial health, and hypothetical debt repayment. Journal of Financial Counseling and Planning, 28(1), 62-75. https://doi.org/10.1891/1052-3073.28.1.62

Kurbanoglu, S. S., Akkoyunlu, B., \& Umay, A. (2006). Developing the information literacy self-efficacy scale. Journal of documentation. 62(6). https://doi. org/10.1108/00220410610714949

Letkiewicz, J. P., Robinson, C. P. C., \& Domian, D. P. C. (2016). Behavioral and wealth considerations for seeking professional financial planning help. Financial Services Review, 25(2), 105-126. https:// doi.org/10.2139/ssrn.2666727

Lim, H., Heckman, S., Montalto, C. P., \& Letkiewicz, J. (2014). Financial stress, self-efficacy, and financial help-seeking behavior of college students. Journal of Financial Counseling and Planning, 25(2), 148-160. 
Marsden, M., Zick, C. D., \& Mayer, R. N. (2011). The value of seeking financial advice. Journal of family and economic issues, 32(4), 625-643. https://doi. org/10.1007/s10834-011-9258-Z

Shefrin, H. M., \& Thaler, R. H. (1988). The Behavioral Life-Cycle Hypothesis. Economic Inquiry, 26(4), 609. https://doi.org/10.1111/j.1465-7295.1988. tb01520.x

Shih, T.-y., \& Ke, S.-c. (2014). Determinates of financial behavior: insights into consumer money attitudes and financial literacy. Service Business, 8(2), 217-238. https://doi.org/10.1007/s11628-0130194-X

Stolper, O. A., \& Walter, A. (2017). Financial literacy, financial advice, and financial behavior. Zeitschrift für Betriebswirtschaft, 87(5), 581-643. https://doi. org/10.1007/s11573-017-0853-9

Strömbäck, C., Lind, T., Skagerlund, K., Västfäll, D., \& Tinghög, G. (2017). Does self-control predict financial behavior and financial well-being? Journal of Behavioral and Experimental Finance, 14, 30-38. https://doi.org/10.1016/j.jbef.2017.04.002

Sundarasen, S. D. D., Rahman, M. S., Othman, N. S., \& Danaraj, J. (2016). Impact of Financial Literacy, Financial Socialization Agents, and Parental
Norms on Money Management. Journal of Business Studies Quarterly, 8(1), 137-153.

Tang, N., \& Peter, P. C. (2015). Financial knowledge acquisition among the young: The role of financial education, financial experience, and parents' financial experience. Financial Services Review, 24(2), 119-137.

Tangney, J. P., Baumeister, R. F., \& Boone, A. L. (2004). High self-control predicts good adjustment, less pathology, better grades, and interpersonal success. Journal of personality, 72(2), 271-324. https:// doi.org/10.1111/j.0022-3506.2004.00263.x

Warschauer, T. P. C. F. P., \& Sciglimpaglia, D. P. (2012). The economic benefits of personal financial planning: An empirical analysis. Financial Services Review, 21(3), 195-208.

\section{Review}

This article was accepted under the constructive peer review option. For futher details, see the descriptions at:

http://mumabusinessreview.org/peer-review-options/

\section{Author}

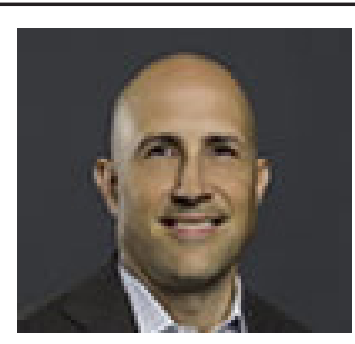

Chad Jones is a retired military officer with over 20 years of service with the US Army. He is currently a wealth management professional with Allen \& Company, holding a Series 7, Series 66, 215 and $\mathrm{CFP}^{\circledR}$ designation. Chad earned his Bachelor of Science in Business Administration from the College of Charleston (South Carolina), an MBA from Webster University (St. Louis, Missouri) and is a member of the DBA Cohort 2021 at the University of South Florida Muma College of Business. 